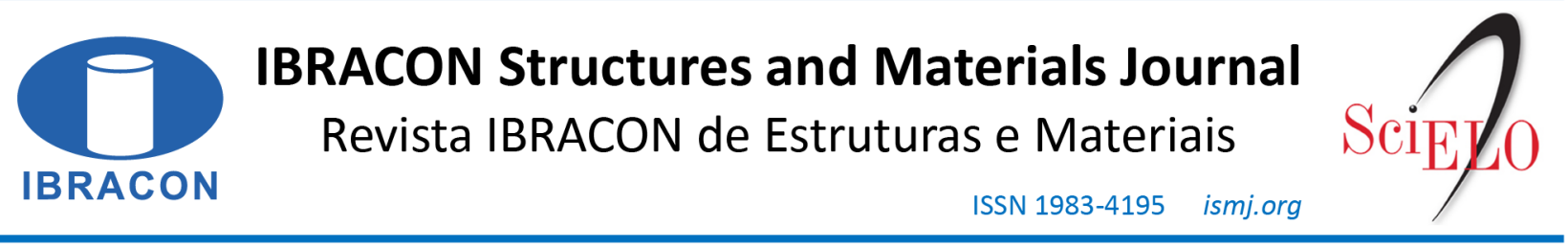

ORIGINAL ARTICLE

\title{
Experimental analysis of steel fiber reinforced concrete beams in shear
}

\section{Análise experimental de vigas de concreto armado com fibra de aço ao cisalhamento}

\author{
Aaron Kadima Lukanu Lwa Nzambia \\ Dênio Ramam Carvalho de Oliveira ${ }^{\mathrm{a}}$ \\ Marcus Vinicius dos Santos Monteiro ${ }^{\mathrm{a}}$ (D) \\ Luiz Felipe Albuquerque da Silva ${ }^{a}$ (D)
}

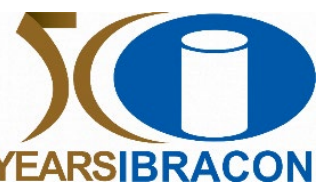

${ }^{a}$ Universidade Federal do Pará - UFPA, Departamento de Engenharia Civil, Belém, PA, Brasil

Received 03 December 2020

Accepted 10 September 2021

\begin{abstract}
Some normative recommendations are conservative in relation to the shear strength of reinforced concrete beams, not directly considering the longitudinal reinforcement rate. An experimental program containing 8 beams of $(100 \times 250) \mathrm{mm}^{2}$ and a length of $1,200 \mathrm{~mm}$ was carried out. The concrete compression strength was $20 \mathrm{MPa}$ with and without $1.00 \%$ of steel fiber addition, without stirrups and varying the longitudinal reinforcement ratio. Comparisons between experimental failure loads and main design codes estimates were assessed. The results showed that the increase of the longitudinal reinforcement ratio from $0.87 \%$ to $2.14 \%$ in beams without steel fiber led to an improvement of $59 \%$ in shear strength caused by the dowel effect, while the corresponding improvement was of only $22 \%$ in fibered concrete beams. A maximum gain of $109 \%$ in shear strength was observed with the addition of $1 \%$ of steel fibers comparing beams with the same longitudinal reinforcement ratio (1.2\%). A significant amount of shear strength was provided by the inclusion of the steel fibers and allowed controlling the propagation of cracks by the effect of stress transfer bridges, transforming the brittle shear mechanism into a ductile flexural one. From this, it is clear the shear benefit of the steel fiber addition when associated to the longitudinal reinforcement and optimal values for this relationship would improve results.
\end{abstract}

Keywords: shear strength, concrete with steel fibers, beams without stirrups.

Resumo: Algumas recomendações normativas são conservadoras em relação à resistência ao cisalhamento de vigas de concreto armado, não levando diretamente em consideração a taxa de armadura longitudinal. Assim, foi realizado um experimento contendo 8 vigas de $(100 \times 250) \mathrm{mm}^{2}$ e comprimento de $1.200 \mathrm{~mm}$, com concreto de resistência à compressão de $20 \mathrm{MPa}$ com e sem adição de 1,00\% de fibra de aço, sem estribos e variando-se a taxa de armadura de flexão. As capacidades de cisalhamento experimentais em comparação com as estimativas das principais normas foram analisadas. Os resultados mostraram que o aumento da taxa de armadura longitudinal de $0,87 \%$ para $2,14 \%$ em vigas sem fibra de aço levou a uma melhoria de $59 \%$ na resistência ao cisalhamento causada pelo efeito de pino, enquanto a melhoria correspondente foi de apenas $22 \%$ em vigas de concreto fibroso. Um ganho máximo de $109 \%$ na resistência ao cisalhamento foi observado com a adição de $1 \%$ de fibras de aço comparando vigas com a mesma taxa de armadura longitudinal $(1,2 \%)$. Uma quantidade significativa de resistência ao cisalhamento foi fornecida pela inclusão das fibras de aço e permitiu controlar a propagação de fissuras pelo efeito de pontes de transferência de tensão, transformando o mecanismo de cisalhamento frágil em um mecanismo de flexão dúctil. Assim, fica claro o benefício da adição de fibra de aço para o cisalhamento quando associada à armadura longitudinal e valores ótimos para essa relação podem melhorar os resultados.

Palavras-chave: resistência ao cisalhamento, concreto com fibras de aço, vigas sem estribos.

How to cite: A. K. L. L. Nzambi, D. R. C. Oliveira, M. V. S. Monteiro, and L. F. A. Silva, "Experimental analysis of steel fiber reinforced concrete beams in shear" Rev. IBRACON Estrut. Mater., vol. 15, no. 3, e15301, 2022, https://doi.org/10.1590/S1983-41952022000300001

Corresponding author: Aaron Kadima Lukanu Lwa Nzambi. E-mail: aaronkadima@email.com

Financial support: None.

Conflict of interest: Nothing to declare.

Data Availability: The data that support the findings of this study are available from the corresponding author, AKLLN, upon reasonable request. 


\section{INTRODUCTION}

Reinforced concrete (RC) is widely used in several structures around the world. Owing to environmental issues in the steel production chain and its associated high costs, several alternatives and technically viable solutions have been proposed in civil construction applications worldwide, such as the use of new composite materials in structural reinforcement, the production chain of which is ecologically friendly using less expensive and more environmentally friendly manufacturing techniques [1]. Therefore, it is essential to understand the various aspects related to the structural capacity of these elements, as well as the properties of the materials that constitute them.

As far as the use of new materials is concerned, the use of steel fiber reinforced concrete (SFRC) has been increasingly used in structures around the world due to its various structural capacity benefits, which according to Yakoub [2], Amin and Foster [3], Nzambi et al. [1] are the increase in shear strength, tensile strength, flexure and ductility. According to Sahoo and Sharma [4], the correct dosage of steel fiber concrete with a minimum steel fiber content of $1 \%\left(78.5 \mathrm{~kg} / \mathrm{m}^{3}\right)$, can change the beams failure behavior from fragile to ductile, allowing the partial replacement of stirrups in concrete beams and speed in the execution of structures.

Several studies have been developed with SFRC beams without stirrup reinforcement [5], [6], with the objectives of determining the main variables that control the shear behavior. Among these variables are the influence of steel fiber with different longitudinal reinforcement rates, Yavas and Goker [7] and the variation of the fiber volume, Resende et al. [8]. According to Yakoub [2] increasing the steel fibers content may generate an increase in the shear strength and improve the beam ductility.

Experimental results are presented here considering SFRC beams without stirrups tested to failure, varying the reinforcement ratio, thus intending to assess the SFRC beams behavior under shear forces.

\section{DESIGN CODES SPECIFICATIONS}

This section discusses the design models to determine the shear strength of RC and SFRC beams proposed in Model Code 10 [9], ACI 318 [10], ACI 544.4R [11], NBR 16935 [12], NBR 6118 [13], JSCE [14], and to determine the beams flexural strength proposed by Model Code 10 [9].

\subsection{Shear strength design}

The calculation the concrete shear strength capacity of reinforced concrete beams without stirrups and with steel fiber $\left(V_{M C 10, f}\right)$, according to Model Code 10 [9], are given by Equations 1 to 5, where $k_{v}$ is a parameter that depends on the level of approximation (LoA). The Model Code 10 [9] contains four levels of shear strength approximation (LoA I to LoA IV) consisting of increasing levels of calculation complexity to obtain the most accurate results. The LoA II has been analyzed in this study, recommended for design cases and general evaluation of an existing element. The approach used in this level of approximation is based on the Simplified Modified Compression Field Theory (SMCFT).

$V_{M C 10}=V_{c 0}=k_{v} \cdot \sqrt{f_{c k}} \cdot z \cdot b_{w} \quad$ (concrete shear strength capacity)

$k_{v}=\frac{0.4}{1+1500 \cdot \varepsilon_{x}} \cdot \frac{1300}{1000+k_{d g} \cdot z} \quad$ (accuracy level, LoA II)

$k_{d g}=\frac{32}{16+d_{g}} \geq 0.75$

$V_{M C 10, f}=\left\{0.18 \cdot k \cdot\left[100 \cdot \frac{A_{s}}{b_{w} \cdot d} \cdot\left(1+7.5 \cdot \frac{f_{F t u k}}{f_{c t k}}\right) \cdot f_{c k}\right]^{\frac{1}{3}}+0.15 \cdot \sigma_{c p}\right\} \cdot b_{w} \cdot d$

(fibers contribution) 
$f_{F t u k}=f_{F t s}-0.6 \cdot\left(f_{F t s}-0.5 \cdot f_{R 3}+0.2 \cdot f_{R 1}\right) \geq 0$

Where $z$ is the internal lever arm between the flexural tensile and compressive forces $(z \approx 0.9 \cdot d) ; \varepsilon_{x}$ is the longitudinal strains calculated at distance $z / 2 ; k_{d g}$ is an aggregate size influence parameter; $d_{g}$ is the maximum aggregate size $\left(d_{g}=9.5 \mathrm{~mm}\right) ; k$ is a factor that takes into account the size effect calculated as $k=1+\sqrt{200 / d} \leq 2.0$ for the effective depth of cross-section $(d) ; f_{F t u k}$ is the characteristic value of the residual strength in the ultimate limit state (ULS), 0.6 takes into account the ultimate crack opening $\left(w_{u}=1.5\right)$ over $\mathrm{CMOD}_{3}(2.5)$. It is possible to avoid the use of conventional shear reinforcement (stirrups) if the limitation of $f_{F t u k} \geq \sqrt{f_{c k}} / 20$ is respected; $f_{c t k}$ is the characteristic tensile strength of concrete given as $0.3 \cdot\left(f_{c k}\right)^{\frac{2}{3}} ; f_{F t s}$ is the value of the residual tensile strength in the service limit state and can be taken as $0.45 \cdot f_{R 1} ; \sigma_{c p}$ is average normal stress acting on concrete cross section due to loading or prestressing. In this paper, the normal stress is zero.

The values of $f_{R 1}$ and $f_{R 3}$ represent residual flexural strength parameters and can be obtained from the load vs CMOD $(\mathrm{CMOD}=$ Crack Mouth Opening Displacement $)$ diagram. In this paper, the empirical approach proposal of Moraes-Neto et al. [15] to determine the residual flexural strengths $f_{R 1}$ and $f_{R 3}$ given by Equations 6 and 7 is considered. The empirical equations of Moraes-Neto et al. [15] were established from the fiber reinforcement index $\left(R I=C_{f} \cdot l_{f} / d_{f}\right)$ that considers the fiber content $\left(C_{f}\right)$ and the fiber aspect ratio $\left(l_{f} / d_{f}\right)$ as the most influential parameters on $f_{R i}$ values. The authors reported a statistical analysis with the data collected from the characterization of the postcracking behavior of SFRC, notched beams subjected to three-point bending tests. Being aware that it is a rather simple approach to simulate the mechanisms of fiber reinforcement since other variables, such as the fiber-matrix bond strength, fiber inclination and fiber embedment length, influence the $f_{R i}$ result values, but this information are often not available in the literature on SFRC of beams or slabs. And according to the authors, a relatively large scatter of results is naturally expected, but this approach is the only possibility to consider the fiber reinforcement in design with the absence of experimental data to predict the theoretical shear strength according to the Model Code 10 [9].

$f_{R 1}=7.5 \cdot R I^{0.8}$

$f_{R 3}=6.0 \cdot R I^{0.7}$

From ACI 318 [10], the shear strength of reinforced concrete beams without stirrups is obtained by Equation 8 . The effect of steel fiber addition is considered by ACI 544.4R [11] which consider the same Equation 1 as Model Code 10 [9] for SFRC. The same procedures were also adopted by NBR 16935 [12], $V_{N B R, f}=V_{A C I, f}=V_{M C 10, f}$, while the shear contribution of concrete without steel fiber is calculated according to NBR 6118 [13], Equation 9.

$V_{A C I}=V_{c 0}=\left(\frac{\lambda \cdot \sqrt{f_{c k}}}{6}\right) \cdot b_{w} \cdot d$

Where, $V_{c 0}=$ concrete contribution to shear capacity (MPa); $\lambda$ is the reduction factor of the mechanical properties of the type of concrete, equal to 1 for normal weight concrete; $f_{c k}=$ concrete compressive strength (MPa); $b_{w}=$ cross section width (mm); and $d=$ effective height (mm).

$V_{N B R}=V_{c 0}=0.126 \cdot f_{c k}^{2 / 3} \cdot b_{w} \cdot d$

JSCE [6] recommends Equations 10 and 11 for calculating the shear strength of reinforced concrete beams without stirrups and with steel fiber. The shear strength resisted by the steel fiber $\left(V_{f}\right)$ is given by Equation 12. For the 
calculation of $f_{t y d}$ corresponding to the tensile yield strength of the concrete, Equation 13 was used, proposed by Choi et al. [16], which considers the fiber content $\left(C_{f}\right)$ and the shape factor of the steel fiber $\left(l_{f} / d_{f}\right)$.

$V_{J S C E}=V_{c 0}=\beta_{d} \cdot \beta_{p} \cdot f_{v c d} \cdot b_{w} \cdot d$ (concrete contribution)

$V_{J S C E, f}=\beta_{d} \cdot \beta_{p} \cdot f_{v c d} \cdot b_{w} \cdot d+V_{f}$ (fibers contribution)

$V_{f}=\frac{f_{t y d} \cdot b_{w} \cdot d}{1.15 \cdot \operatorname{tg} 45^{\circ}}$

$f_{\text {tyd }}=0.292 \cdot\left(f_{c k}\right)^{1 / 2} \cdot\left[1+C_{f} \cdot\left(0.1 \cdot \frac{l_{f}}{d_{f}}-1\right)\right]$

Where, $\beta_{d}=\min \left(\sqrt[4]{\frac{1000}{d}} ; 1.5\right) ; \beta_{p}=\min \left(\sqrt[3]{\frac{1000 \cdot A_{s}}{b_{w} \cdot d}} ; 1.5\right) ; f_{v c d}=\min \left(0.20 \cdot \sqrt[3]{f_{c k}} ; 0.72\right)$ and $A_{s}$ is area of longitudinal tension reinforcement.

\subsection{Flexural strength}

For the calculation of the flexural strength (Equation 14) of conventional and fiber concrete beams, the simplified model proposed by Model Code 10 [9] was adopted, as in Figure 1. The flexural strength parcel due to steel fiber addition is given by $f_{\text {Ftuk }}$, which is previously calculated in Equation 5. The process of calculating the resistant moment, $m_{R}$ (Equation 15) was carried out via an interactive process after reaching the resultant forces balance $\left(\sum F_{i}=0\right)$. According to Model Code 10 [9], the minimum material ductility for structural application, is guaranteed when $f_{R 1, k} / f_{L, k} \geq 0.4$ and $f_{R 3, k} / f_{R 1, k} \geq 0.5$.

$$
V_{\text {flex }}=\frac{2 \cdot m_{R}}{a}
$$

$m_{R}=F_{c} \cdot y_{c}+F_{t} \cdot y_{t}+F_{s} \cdot y_{s}+F_{s}^{\prime} \cdot y_{s}^{\prime}$

Where, $a$ is the shear span; $F_{i}$ and $y_{i}$, respectively, are resultant forces and lever arms.

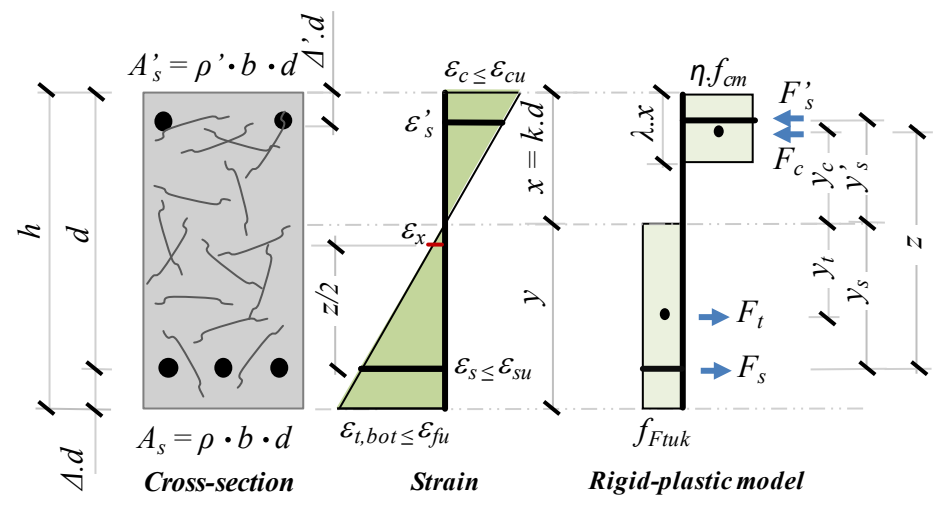

Figure 1. Flexure model of Model Code 10 [9]. 


\section{EXPERIMENTAL PROGRAM}

The experimental program consisted of the testing to failure two series of 4 beams with cross section of (100 x 200) $\mathrm{mm}^{2}$ and length of $1200 \mathrm{~mm}$. The beams were cast without stirrups and with approximately 20-MPa concrete was, with and without the addition of $1 \%$ steel fiber. The variables analyzed were the addition of steel fiber and the variation on the longitudinal reinforcement rate.

\subsection{Materials properties}

The concrete constituent materials used in the beams are presented in Table 1. The ABCP-method [17] was adopted for the concrete mix design using CPII - Z cement and rolled pebble with a maximum diameter of $9.5 \mathrm{~mm}$. In addition, for the SFRC, superplasticizer was used to maintain a good workability and the same ratio w/c. The steel fibers used were type $\mathrm{C}$ according to the classification of the NBR 15530 [18], the flat crimped type (Figure 2a) with length $\left(l_{f}\right)$ of $31 \mathrm{~mm}$, equivalent diameter $\left(d_{f}\right)$ of $1.2 \mathrm{~mm}$ and aspect ratio $\left(l_{f} / d_{f}\right)$ of 25.8 . The characteristics of the reinforcing steel bars (Figure 2b) used in this research were obtained from the axial tensile test, according to NBR 6892 [19], and are presented in Table 2.

Table 1. Mixture Design.

\begin{tabular}{|c|c|c|}
\hline \multirow{2}{*}{ Materials } & \multicolumn{2}{|c|}{ Consumption $\left(\mathrm{Kg} / \mathrm{m}^{3}\right)$} \\
\hline & RC & SFRC \\
\hline Portland CPII-Z32RS Cement & \multicolumn{2}{|c|}{310.61} \\
\hline Coarse aggregate (pebble, $d_{\max }=9.5 \mathrm{~mm}$ ) & \multicolumn{2}{|c|}{1078.53} \\
\hline Fine aggregate (fine sand) & \multicolumn{2}{|c|}{781.49} \\
\hline Water & \multicolumn{2}{|c|}{205} \\
\hline $\mathrm{w} / \mathrm{c}$ & \multicolumn{2}{|c|}{0.64} \\
\hline Steel Fiber & - & 78.6 \\
\hline Superplasticizer Admixture & - & 0.95 \\
\hline
\end{tabular}

Table 2. Steel bars' mechanical properties.

\begin{tabular}{|c|c|c|c|c|}
\hline Location & $\varnothing(\mathbf{m m})$ & $f_{y s}$ (MPa) & $\varepsilon_{y s}(\%)$ & $E_{s}$ (GPa) \\
\hline Stirrups & 4.2 & 651 & 5.20 & 203 \\
\hline \multirow{4}{*}{ Longitudinal reinforcement } & 6.3 & 540 & 4.40 & 225 \\
\hline & 8.0 & 532 & 2.53 & 210 \\
\hline & 10.0 & 521 & 2.45 & 212 \\
\hline & 12.5 & 560 & 2.48 & 225 \\
\hline
\end{tabular}
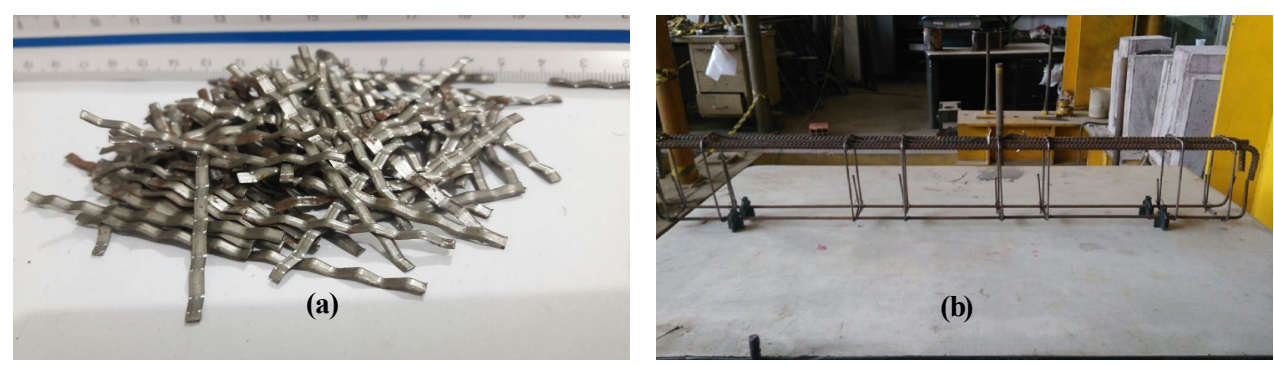

Figure 2. (a) Flat crimped steel fiber [1] and (b) Reinforcing steel bars.

\subsection{Characteristics of beams}

Eight reinforced concrete beams without stirrups were tested to failure, divided into two series with 4 beams each: the RC (VS) series, which does not have the addition of steel fiber, and the SFRC (VF) series, which has the addition of $1 \%$ steel fiber. The longitudinal reinforcement ratio varied from $0.87 \%$ to $2.14 \%$. To measure the strains in the concrete and in the longitudinal reinforcement, electric strength strain gauges (EERs) were used. EXCEL brand sensors 
that were fixed on the central top surface of the beams to measure the strains in the concrete $\left(\mathrm{EER}_{\mathrm{c}}\right.$ - model PA-061500BA-120L), and in the middle of the length of the steel bars to measure the strains in the longitudinal reinforcement $\left(E_{E}\right.$ - model PA-06-125AA-120L). The reading and recording of the data were performed through the Ahlborn ALMEMO ${ }^{8} 5690-2 M$ data acquisition equipment, with AMR WinControl software. The EERS application locations and typical test system details are shown in Figure 3 The EERS models used in concrete and steel are shown respectively in Figures $4 \mathrm{a}$ and $4 \mathrm{~b}$. The section properties are shown in Figure 4c. The beams were moulded and cured for 28 days in the laboratory with $85 \%$ relative air humidity. Three cylindrical concrete specimens $(100 \mathrm{~mm}$ diameter and $200 \mathrm{~mm}$ height) from each mixture were tested to determine the concrete experimental compressive strength. Table 3 presents the summary of the main characteristics of the tested beams.

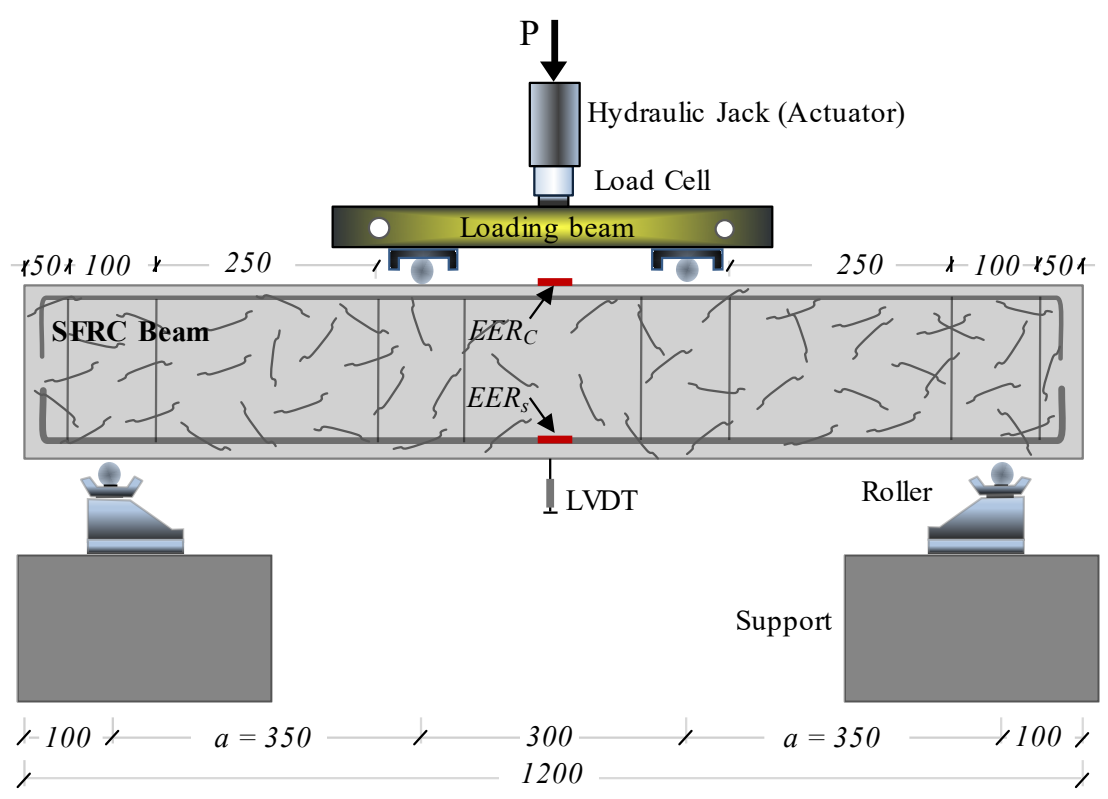

Figure 3. Test schema.
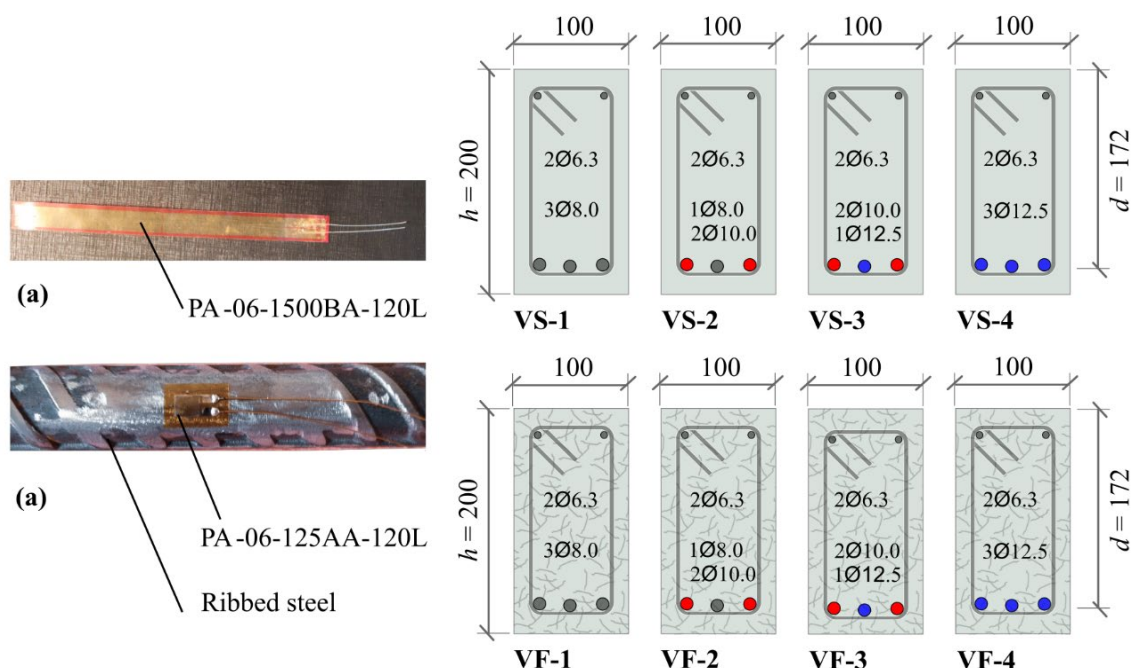

VS-4

(c) Beams' cross-sections

Figure 4. (a) Strain gauges model used for the concrete $\left(E E R_{c}\right)$, (b) Strain gauge on steel bar $\left(E E R_{s}\right)$ and (c) Detailing of beam sections. 
Table 3. Characteristics of beams.

\begin{tabular}{|c|c|c|c|c|c|c|}
\hline Series & Beams & ${ }^{d} \mathbf{( \mathbf { m m } )}$ & $a / d$ & $\rho_{(\%)}$ & $C_{f}(\%)$ & $f_{c}$ (MPa) \\
\hline \multirow{4}{*}{$\mathrm{RC}$} & VS-1 & \multirow{8}{*}{172} & \multirow{8}{*}{2} & 0.87 & \multirow{4}{*}{ - } & 24.0 \\
\hline & VS-2 & & & 1.20 & & 23.1 \\
\hline & VS-3 & & & 1.62 & & 24.7 \\
\hline & VS-4 & & & 2.14 & & 24.2 \\
\hline \multirow{4}{*}{ SFRC } & VF-1 & & & 0.87 & \multirow{4}{*}{1} & 22.8 \\
\hline & VF-2 & & & 1.20 & & 21.5 \\
\hline & VF-3 & & & 1.62 & & 21.7 \\
\hline & $\mathrm{VF}-4$ & & & 2.14 & & 22.0 \\
\hline
\end{tabular}

\subsection{Test setup and procedure}

The test was performed on a TIME brand Hydraulic Universal Testing Machine (HUTM) with 1,000-kN capacity of and closed-loop displacement control. The beams were positioned so that they were loaded in four points (Figure 5) The distance between each the load application point to the support was $350 \mathrm{~mm}$. The load consisted of two concentrated loads $300 \mathrm{~mm}$ apart. During the load application process, the test machine monitored the applied displacement and load while the data acquisition equipment recorded the strains in concrete and steel.

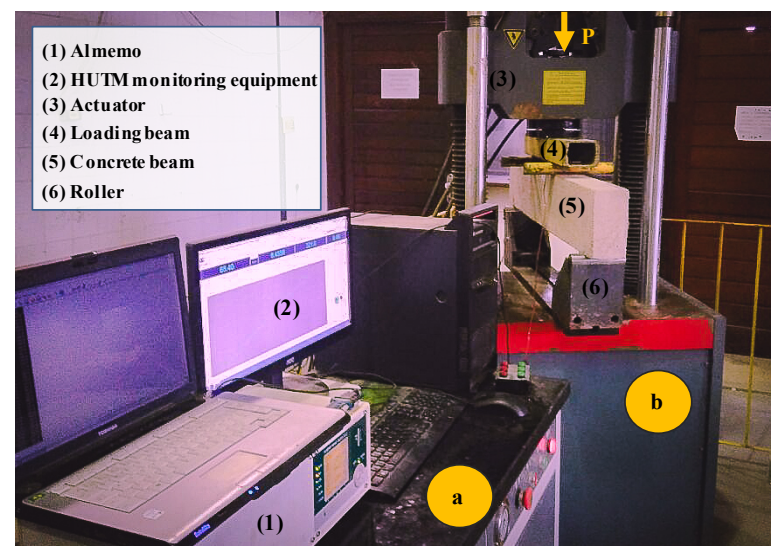

Figure 5. (a) Data acquisition equipment and (b) HUTM assembled test system.

\section{RESULTS AND DISCUSSIONS}

Table 4 shows the summary of the experimental results, including the experimental shear strength $\left(V_{E x p}\right)$, the ultimate shear force $\left(V_{c o r t, u}=V_{E x p} / 2\right)$, the ultimate shear stress $\left(v_{u}=V_{c o r t, u} / b \cdot d\right)$, and the beam failure modes. All beams failed by shear and the SFRC beam series showed higher strength and consequently higher shear strength capacity (Figure 6).

Table 4. Loads and failure modes of the beams.

\begin{tabular}{|c|c|c|c|c|c|c|c|}
\hline Series & Beam & $\rho(\%)$ & $f_{c}$ (MPa) & $V_{\operatorname{Exp}}(\mathrm{kN})$ & $V_{\text {cort }, u}(\mathbf{k N})$ & $v_{u}{ }_{(\mathrm{MPa})}$ & Failure mode \\
\hline \multirow{4}{*}{$\mathrm{RC}$} & VS-1 & 0.87 & 24.0 & 35.5 & 17.8 & 1.0 & \multirow{8}{*}{ Shear } \\
\hline & VS-2 & 1.20 & 23.1 & 36.2 & 18.1 & 1.1 & \\
\hline & VS-3 & 1.62 & 24.7 & 48.9 & 24.5 & 1.4 & \\
\hline & VS-4 & 2.14 & 24.2 & 56.6 & 28.3 & 1.7 & \\
\hline \multirow{4}{*}{ SFRC } & VF-1 & 0.87 & 22.8 & 63.5 & 31.8 & 1.9 & \\
\hline & VF-2 & 1.20 & 21.5 & 75.7 & 37.9 & 2.2 & \\
\hline & VF-3 & 1.62 & 21.7 & 76.3 & 38.2 & 2.2 & \\
\hline & VF-4 & 2.14 & 22.0 & 77.7 & 38.9 & 2.3 & \\
\hline
\end{tabular}



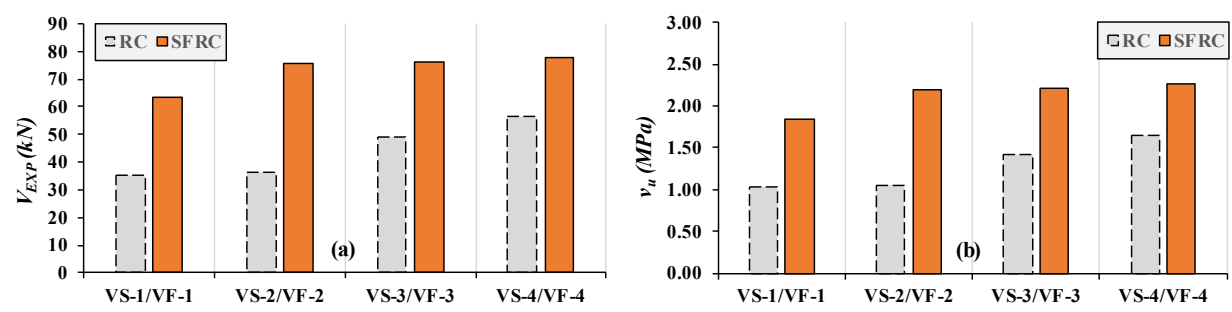

Figure 6. (a) Shear strength and (b) Shear stress.

\subsection{Failure modes}

The beams failure modes were all the same, shear with diagonal tensile, as expected, since the beams had no conventional shear reinforcement. Figure 7 shows the failure pattern of the VS-2 and VF-2 beams, which was similar for all beams. Sudden failures with large openings of diagonal cracks were observed in RC beams, while SFRC beams had ductile failures, keeping smaller widths openings cracks as shown in Figure 8. This behaviour is like that reported by Amin and Foster [3]. The shear stress transfer capacity in SFRC generated high failure loads strengths. According to Nzambi et al. [1], the introduction of steel fibers has a significant effect on improving the bond stress performance in terms of the failure load strength, resulting in a more ductile bonding behaviour of reinforcing bars with smaller diameters and the contribution of stress redistribution in the cracked cross-section through the steel fiber bridging effect. Also, concrete peeling was observed more expressively in RC beams, a typical characteristic of dowel effect.
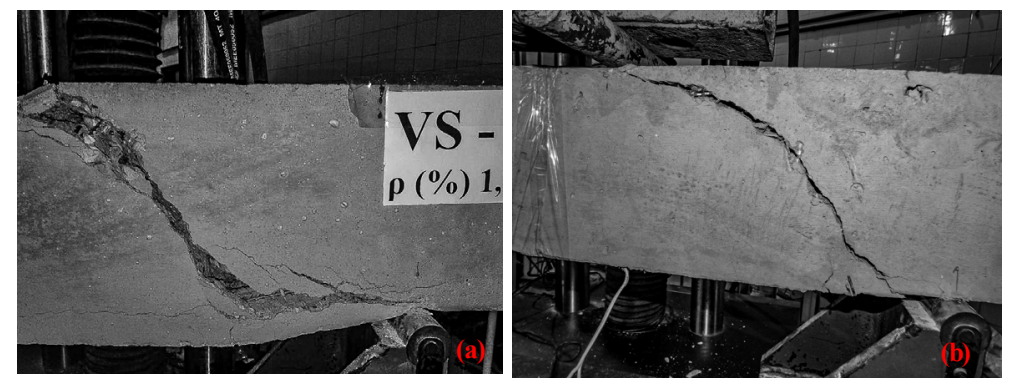

Figure 7. Failure pattern: (a) RC e (b) SFRC.
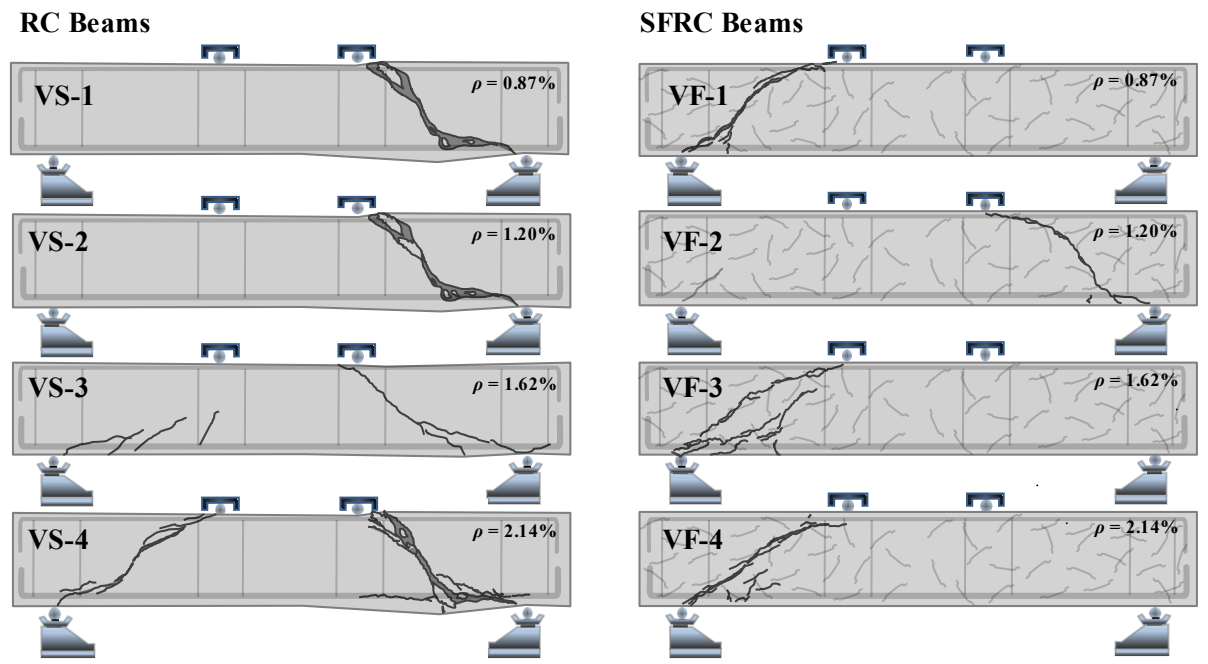

Figure 8. Crack patterns. 


\subsection{Strains and failure loads}

In general, all beams showed similar strains patterns, with ultimate strains lower than $3.5 \%$, indicating that there was no concrete crushing. Figure 9 shows the concrete strains for the RC and SFRC series beams, respectively. For the $\mathrm{RC}$ beam series, all strains in the longitudinal reinforcement were less than $2.3 \%$, indicating that there was no yielding of longitudinal reinforcement, which was expected since the beams had no stirrups. In the SFRC series beams, all the beams had strains in the longitudinal reinforcements higher than in the RC series beams due to the addition of $1 \%$ steel fiber. In this series it was also observed a decrease in the strains of the longitudinal reinforcement with the increase of the rate of longitudinal reinforcement. Figure 10 shows the strains of the rebar for the RC and SFRC series beams.
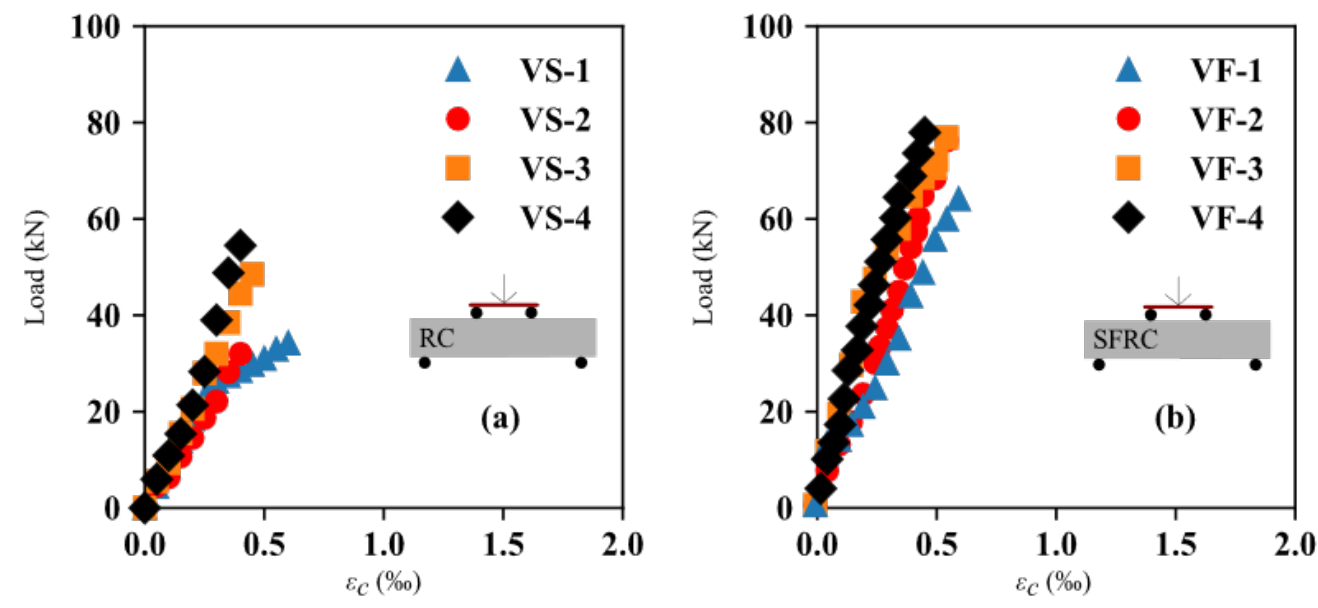

Figure 9. Concrete strains for RC and SFRC series.
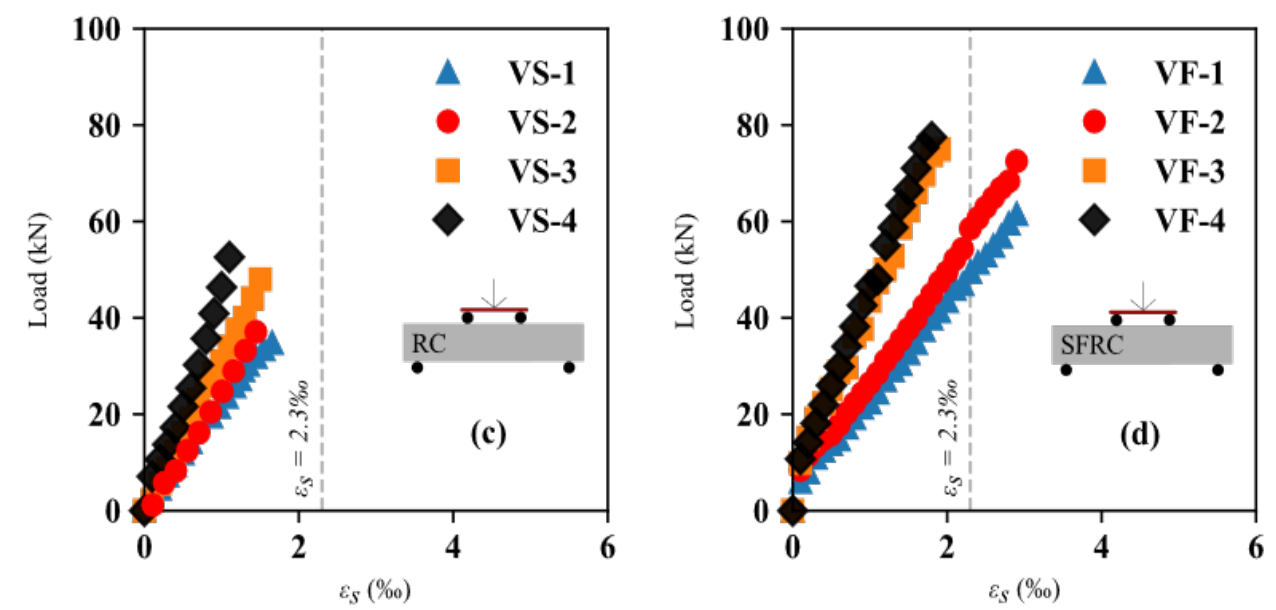

Figure 10. Strains in the longitudinal reinforcement for RC and SFRC series.

\subsection{Effect of longitudinal reinforcement}

The SFRC series beams showed, on average, an increase in strength of $70 \%$ compared to the RC series beams. The influence of the increase in longitudinal reinforcement was evident in the two beams series, as shown in Figure 11. For the RC beams series this influence was evident by the progressive increase in shear strength with the increase in the longitudinal reinforcement rate. This increase in strength was on average approximately equal to $25 \%$ and confirms that the longitudinal reinforcement rate provides a relevant contribution in the shear strength of concrete beams without steel fiber. It was evident that the reinforcement ratio over $1 \%$ allowed an increase up to $20 \%$ in the shear strength in SFRC, as observed in beams VF-1 and VF-2. 


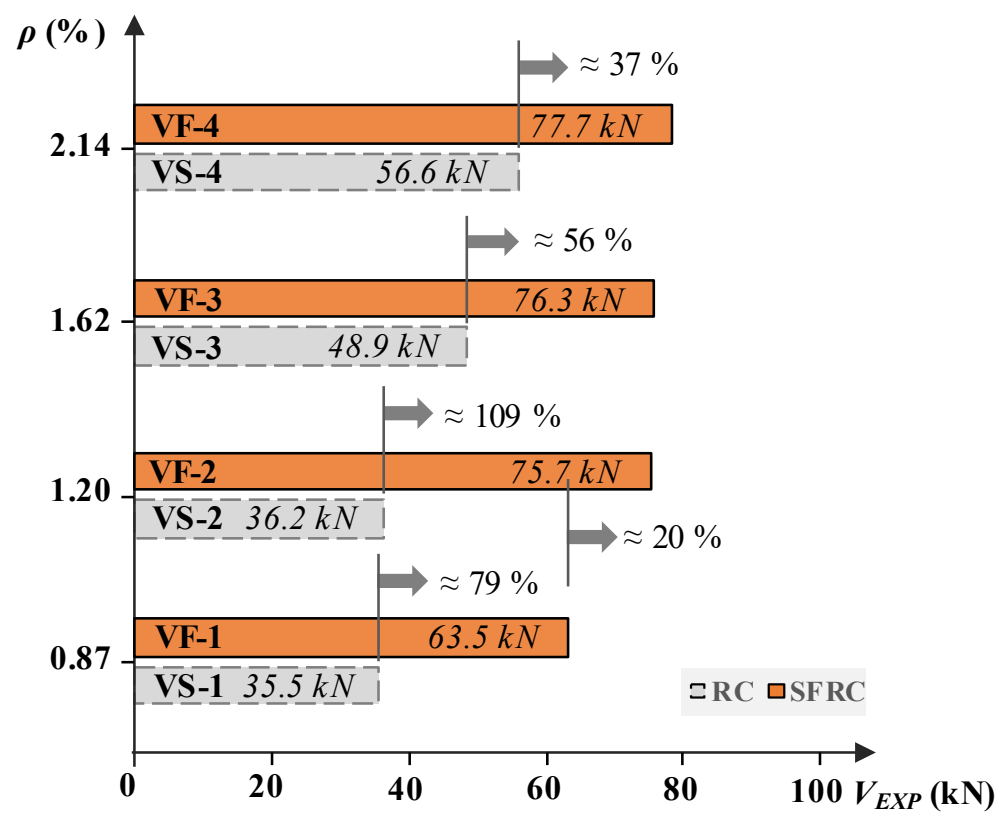

Figure 11. Shear strength of the beams and strength gain.

\subsection{Comparison between experimental and estimates}

Table 5 presents the estimates of flexural and shear strength by Model Code 10 [9] compared with the experimental strength $\left(V_{E x p}\right)$. The Table also presents the relationship $V_{f l e x} / V_{M C 10}$ [20], which represents an estimate for the failure modes of the beams, which can be by shear with $V_{f l e x} / V_{M C 10}>1.0$ or by flexure with $V_{f l e x} / V_{M C 10}<1.0$. The results presented by the ratio $V_{\text {flex }} / V_{M C 10}$ indicated that all beams presented shear failure, as observed in the tests. Figures $12 \mathrm{a}$ and $12 \mathrm{~b}$ clearly show the behavior of the flexural reinforcement influence in the failure mode, a similar linear behavior for both the RC beams and the SFRC beams. With the increase in the reinforcement rate, the beams tend to fail more by shear and the addition of $1 \%$ of fiber volume in the concrete influenced the reduction on the results dispersion [1], and provided the lowest values of the $V_{\text {flex }} / V_{\text {Exp }}$ ratio in comparison with the RC beam series.

Table 5. Failure mode evaluation.

\begin{tabular}{|c|c|c|c|c|c|c|c|}
\hline Type & Beam & $\begin{array}{c}V_{f l e x} \\
(\mathbf{E q} \cdot 15) \\
(\mathbf{k N}) \\
\end{array}$ & $\begin{array}{l}V_{\text {Exp }} \\
(\mathrm{kN}) \\
\end{array}$ & $\begin{array}{c}V_{M C 10} \\
(\mathbf{k N}) \\
\end{array}$ & $V_{f l e x} / V_{E x p}$ & $V_{f l e x} / V_{M C 10}$ & Failure mode \\
\hline \multirow{4}{*}{$\mathrm{RC}$} & VS-1 & 71.1 & 35.5 & 57.0 & 2.0 & 1.2 & \multirow{8}{*}{ Shear } \\
\hline & VS-2 & 94.5 & 36.2 & 55.7 & 2.6 & 1.7 & \\
\hline & VS-3 & 122.8 & 48.9 & 55.4 & 2.5 & 2.2 & \\
\hline & VS-4 & 153.5 & 56.6 & 56.9 & 2.7 & 2.7 & \\
\hline \multirow{4}{*}{ SFRC } & VF-1 & 76.2 & 63.5 & 52.0 & 1.2 & 1.6 & \\
\hline & VF-2 & 100.0 & 75.7 & 57.2 & 1.3 & 1.8 & \\
\hline & VF-3 & 128.4 & 76.3 & 63.1 & 1.7 & 2.1 & \\
\hline & VF-4 & 158.9 & 77.7 & 69.5 & 2.0 & 2.3 & \\
\hline
\end{tabular}



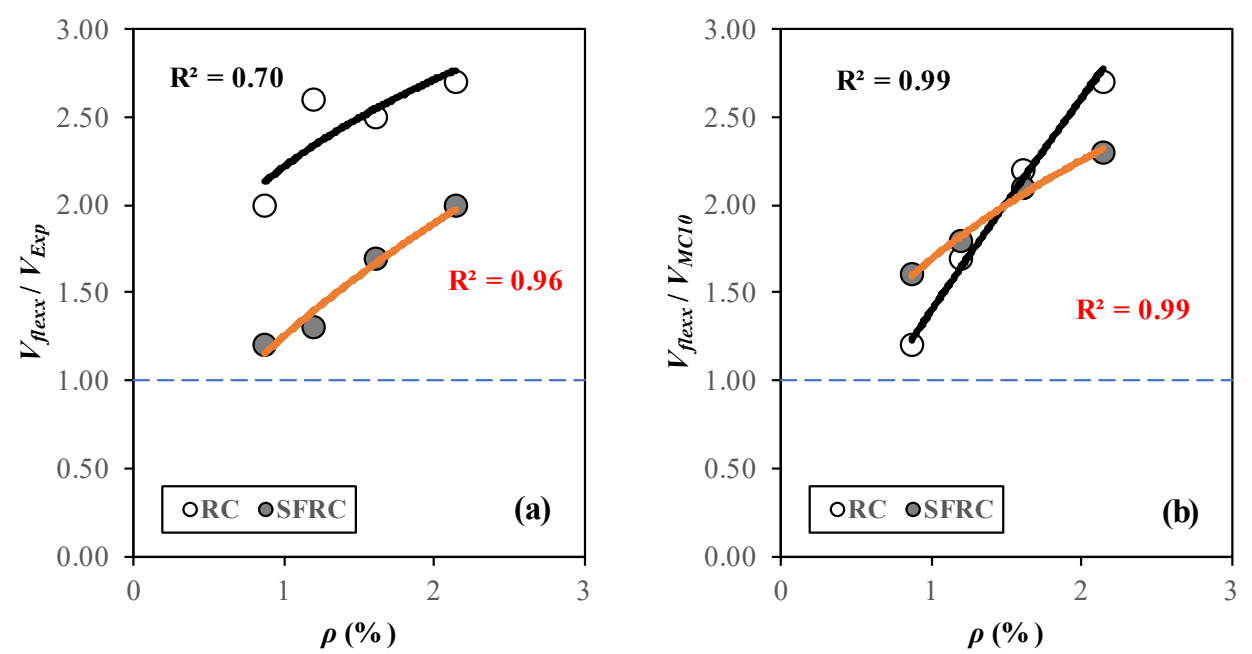

Figure 12. Influence of the flexural reinforcement rate on the failure mode: (a) Comparison with the $V_{\text {flex }} / V_{\text {Exp }}$ relationship and (b) Comparison with the $V_{f l e x} / V_{M C 10}$ relationship.

Table 6 presents the relationship between the experimental loads and the loads estimated by Model Code 10 [9], ACI 318 [10], ACI 544.4R [11], NBR 16935 [12], NBR 6118 [13], and JSCE [14]. In general, the effect of fiber in SFRC tends to reduce the variability of results by around $6 \%$ compared to RC which was between $11 \%$ for JSCE [14], 23\% for Model Code 10 [1] and ACI 318 [10], and 24\% for NBR 6118 [13], while figures 13a and 13b clearly show the variability of this comparison of experimental $\left(V_{E x p}\right)$ and normative shear strength.

It was observed that for the RC beam series, the Model Code 10 [9] overestimated the shear strength of the beams by approximately $40 \%$ with a reinforcement rate of $0.87 \%$ and $1.2 \%$. The most conservative results were obtained with ACI 318 [10], which presented on average strength values $60 \%$ lower than the experimental results. The most accurate results for this series of beams were calculated with JSCE [14], obtaining average strength values $32 \%$ lower in relation to the experimental results, but it was observed that the Japanese standard was not able to predict the strength gain of $60 \%$ occurred between beams VS-1 and VS-4, provided by the increased rate of longitudinal reinforcement. The lowest coefficient of variation (11\%) was also observed with the JSCE [14].

Table 6. Results estimated by the standards.

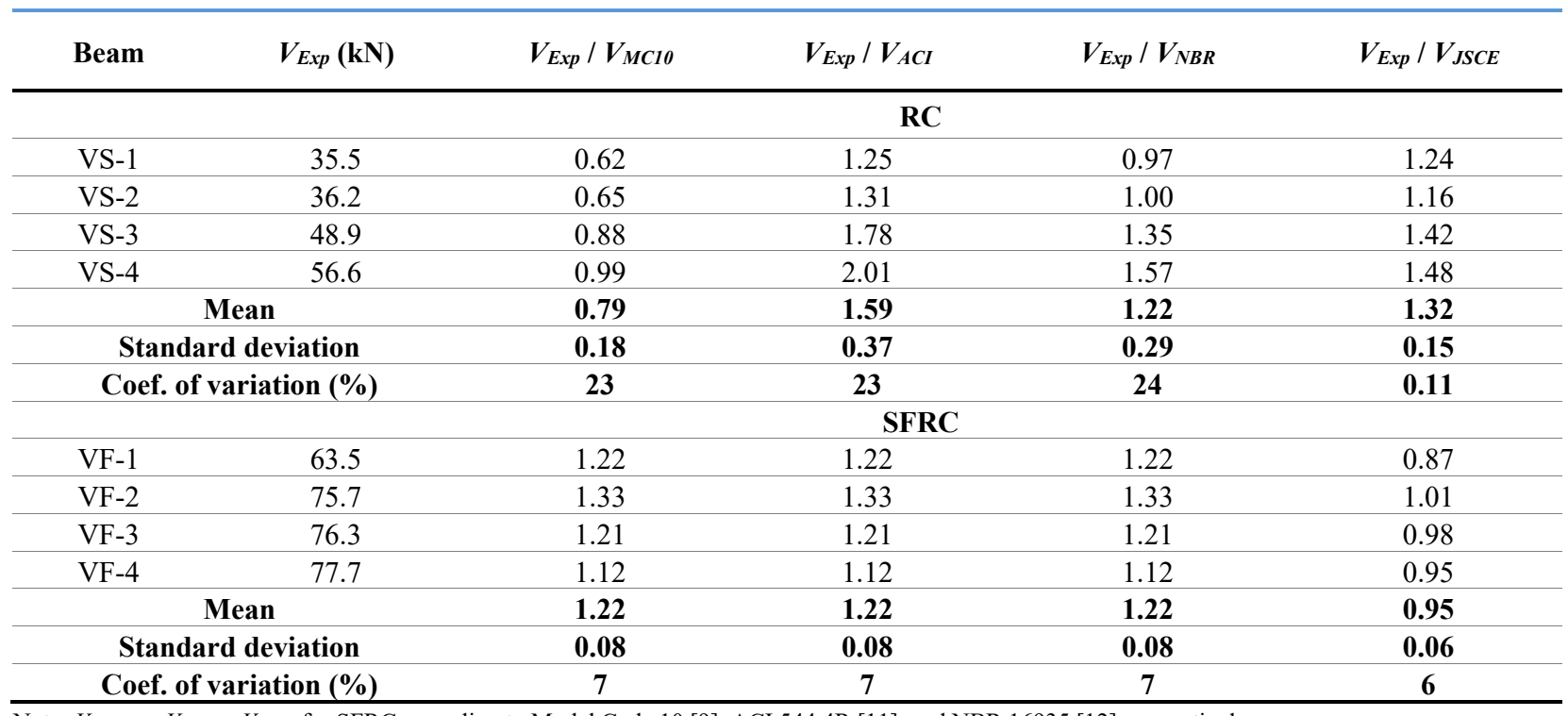

Note: $V_{M C 10, f}=V_{A C l, f}=V_{N B R, f}$ for SFRC according to Model Code 10 [9], ACI 544.4R [11], and NBR 16935 [12], respectively. 

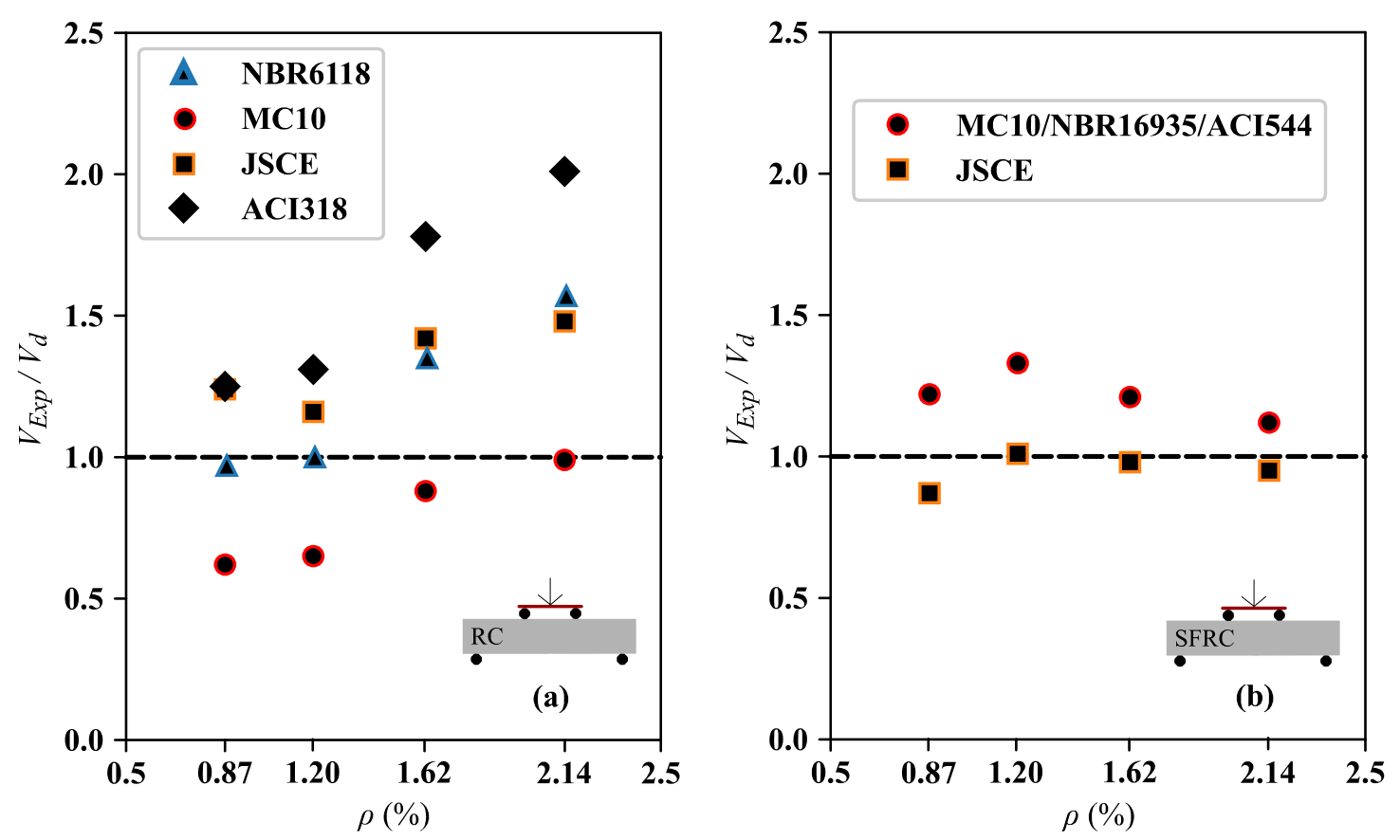

Figure 13. Relationship between experimental and shear strength estimates: (a) With the series of beams without fiber and (b) With the series of beams with fiber.

In the analysis of the SFRC series beams, the most accurate results were obtained by JSCE standards [14], which presented average strength values very close to those obtained experimentally, but for the reinforcement rate of $0.86 \%$, the standards overestimated the results by approximately $15 \%$. The most conservative results were obtained by NBR 16935 [12], Model Code 10 [9] and ACI 544.4R [11], which presented, on average, results 22\% lower than the experimental results, showing the imprecision of the standard in predicting the shear strength of SFRC beams.

\subsection{Characterization of the material class and classification}

The stress-crack opening relationship in uniaxial tensile characterizes the post-cracking behavior of the material. According to Model Code 10 [9], the $f_{R l, k}$ strength values indicate the material classes, ranging from $1 \mathrm{MPa}$ to $8 \mathrm{MPa}$. Whereas the $f_{R 3, k} / f_{R l, k}$ ratio is denoted by the letters a, b, c, d, e, corresponds to the classification presented in Table 7 , softening or hardening materials.

Table 8 presents the residual stresses at flexure $\left(f_{R I, d}\right.$ and $\left.f_{R 3, d}\right)$ and at tensile $\left(f_{F T S}\right.$ and $\left.f_{F t u}\right)$ obtained from the material class, indicating a softening behavior (Figure 14a). Two simplified stress-crack opening constitutive laws may be deduced from the tensile results with the Model Code 10 [9], a linear post-cracking model or a rigid-plastic model, as shown in Figures $14 \mathrm{~b}$ and $14 \mathrm{c}$. It is interesting to note that the empirical models for calculating residual stresses proposed by Moraes-Neto et al. [15] were satisfactory in predicting the failure mode and material behavior with the Model Code 10 [1].

Table 7. Classification according to Model Code 10 [9]

\begin{tabular}{ccc}
\hline Class & $\boldsymbol{f}_{\boldsymbol{R}, \boldsymbol{k}} / \boldsymbol{f}_{\boldsymbol{R}, \boldsymbol{k} \boldsymbol{k}}$ & Behavior \\
\hline $\mathrm{a}$ & 0.5 & Softening \\
\hline $\mathrm{b}$ & 0.7 & \\
$\mathrm{c}$ & 0.9 & Hardening \\
\hline $\mathrm{d}$ & 1.1 & \\
\hline $\mathrm{e}$ & 1.3 & \\
\hline
\end{tabular}


Table 8. Residual stresses at SFRC flexure and tensile (Model Code 10) [9]

\begin{tabular}{|c|c|c|c|c|c|c|c|c|}
\hline \multirow[b]{2}{*}{ Type } & \multirow[b]{2}{*}{ Beam } & \multirow[b]{2}{*}{ Class } & \multicolumn{2}{|c|}{ Flexure } & \multicolumn{2}{|c|}{ Tensile } & \multicolumn{2}{|c|}{ Classification } \\
\hline & & & $f_{R 1, d}(\mathrm{MPa})$ & $f_{R 3, d}(\mathrm{MPa})$ & $f_{F t s}(\mathrm{MPa})$ & $\begin{array}{l}f_{F t u k, k} \\
\text { (MPa) }\end{array}$ & $f_{R 3, d} / f_{R 1, d}$ & Behavior \\
\hline \multirow{4}{*}{ SFRC } & VF-1 & \multirow{4}{*}{$2.5 \mathrm{c}$} & \multirow{4}{*}{2.5} & \multirow{4}{*}{2.3} & \multirow{4}{*}{1.1} & \multirow{4}{*}{0.65} & \multirow{4}{*}{$0.92 *$} & \multirow{4}{*}{ Softening } \\
\hline & VF-2 & & & & & & & \\
\hline & VF-3 & & & & & & & \\
\hline & VF-4 & & & & & & & \\
\hline
\end{tabular}

Note: * value obtained empirically [15].
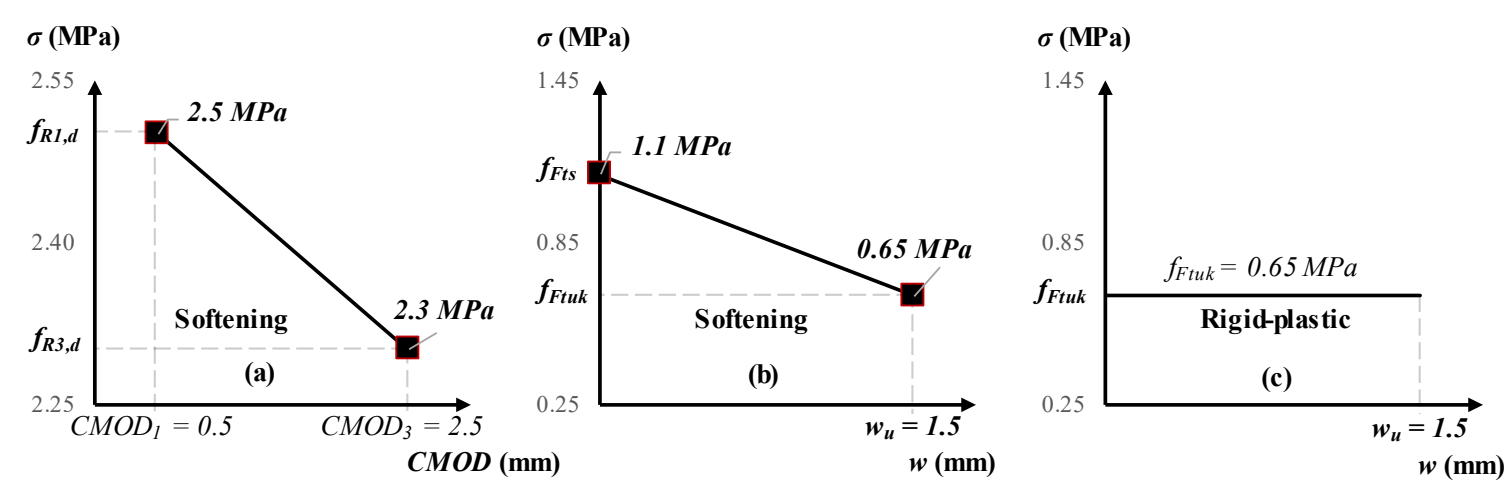

Figure 14. (a) Flexural response, (b) Softening Tensile response and (c) Rigid-plastic Tensile response

\section{CONCLUSIONS}

In this work the shear strength of beams with and without the addition of steel fiber were analyzed. A total of 8 beams without stirrups were tested, having as variables the addition of $1 \%$ of steel fiber and the variation of the longitudinal reinforcement rate. The results showed that the increase of the longitudinal reinforcement ratio from $0.87 \%$ to $2.14 \%$ in beams without steel fiber led to an improvement of $59 \%$ in shear strength caused by the dowel effect [8], observed between VS-1 and VS-4 beams, while the corresponding improvement was of only $22 \%$ in fibered concrete beams. A maximum gain of $109 \%$ in shear strength was observed with the addition of $1 \%$ of steel fibers comparing beams (VS-2 and VF-2) with the same longitudinal reinforcement ratio (1.2\%). A significant amount of shear strength was provided by the inclusion of the steel fibers and allowed controlling the propagation of cracks by the effect of stress transfer bridges, transforming the brittle shear mechanism into a ductile flexural one.

Regarding the estimates of the standards for the RC beams, the results of NBR 6118 [13], JSCE [14] and ACI 318 [10] were conservative, while the Model Code 10 [9] was against safety in concrete with low compressive strength $\left(f_{c}\right.$ $\leq 25 \mathrm{MPa}$ ), but the ACI 318 [10] was inaccurate in predicting the increase in strength when the rate of longitudinal reinforcement was varied, comparing VS-1 and VS-4, the JSCE [14] had an increase of 33\% against $60 \%$ of experimental results.

For SFRC beams, the most accurate standards were JSCE [14] with a coefficient of variation of only 6\%. For this series of beams the Model Code 10 [9], ACI 544.4R [11] and NBR 16935 [12] were the most conservative, recommending strength values lower than the JSCE [14] and the experimental results. Although 1\% of fiber volume was insufficient to provide flexural failure, the results obtained show the potential possibility of using fibers to reduce the rate of longitudinal reinforcement in flexural strength.

\section{NOTATION}

$a$ = shear span;

$A_{S}=$ area of longitudinal tension reinforcement;

$A_{S}^{\prime}=$ area of longitudinal compression reinforcement;

$b_{w}=$ width of the beam cross section; 
$C_{f}=$ fiber content;

$d$ = effective depth of the beam;

$d_{f}=$ fiber diameter;

$d_{g}=$ maximum aggregate size;

$\varepsilon_{x}=$ is the longitudinal strain;

$f_{c k}=$ characteristic concrete cylinder compressive strength;

$f_{c m}=$ average measured concrete cube compressive strength;

$f_{c t k}=$ characteristic tensile strength of concrete;

$f_{F t s}=$ residual tensile strength in the service limit state;

$f_{\text {Ftuk }}=$ residual strength characteristic to last limit state;

$f_{\text {tyd }}=$ corresponds to the tensile strength of the concrete, Equation 12, proposed by CHOI et al. (2007);

$f_{y s}=$ yield strength of the steel stirrups;

$f_{R 1}$ e $f_{R 3}=$ residual flexural strengths [15];

$k_{d g}=$ coefficient that depends on the maximum aggregate size;

$l_{f}=$ fiber length;

$m_{R}=$ strength moment;

$V_{c 0}=$ concrete contribution to shear capacity;

$V_{d}=$ design shear capacity;

$V_{f}=$ design shear capacity of the steel fiber contribution;

$V_{f l e x}=$ flexural strength;

$V_{A C I}=$ shear capacity calculated by ACI 318 and ACI544.4R;

$V_{E x p}=$ ultimate experimental shear capacity;

$V_{J S C E}=$ shear capacity calculated by JSCE;

$V_{M C 10}=$ shear capacity calculated by Model Code10;

$w_{u}=$ maximum crack opening accepted in structural design;

$\mathrm{z}=$ internal lever arm;

$\varepsilon_{c}=$ concrete compressive strain;

$\varepsilon_{S}=$ strain in steel reinforcement;

$\lambda=$ reduction factor of the mechanical properties of the type of concrete;

$\rho=$ tensile reinforcement ratio;

$\rho^{\prime}=$ compressive reinforcement ratio;

$\sigma_{c p}=$ average normal stress acting on concrete cross section due to loading.

\section{ACKNOWLEDGEMENTS}

The authors thank to CNPq and CAPES for the financial support.

\section{REFERENCES}

[1] A. K. L. L. Nzambi, D. R. C. Oliveira, A. M. Oliveira, and M. S. Picanço, "Pull-out tests of ribbed steel reinforcing bars embedded in concrete with steel fibres," Proc. Inst. Civ. Eng., Struct. Build., vol. 174, no. 3, pp. 181-189, 2021, http://dx.doi.org/10.1680/jstbu.17.00180.

[2] H. E. Yakoub, "Shear stress prediction: steel fiber-reinforced concrete beams without stirrups," ACI Struct. J., vol. 103, no. 3, pp. 304-444, 2011, http://dx.doi.org/10.14359/51682346.

[3] A. Amin and S. J. Foster, "Shear strength of steel fibre reinforced concrete beams with stirrups," Eng. Struct., vol. 111, pp. 323-332, 2016, http://dx.doi.org/10.1016/j.engstruct.2015.12.026.

[4] D. R. Sahoo and A. Sharma, "Effect of steel fiber content on behavior of concrete beams with and without stirrups," ACI Struct. J., vol. 111, no. 5, pp. 1157-1167, 2014, http://dx.doi.org/10.14359/51686821.

[5] G. J. Parra-Montesinos, "Shear strength of beams with deformed steel fibers," Concr. Int., vol. 28, no. 11, pp. 57-66, 2006. 
[6] N. D. Tung and N. V. Tue, "Shear resistance of steel fiber-reinforced concrete beams without conventional shear reinforcement on the basis of the critical shear band concept," Eng. Struct., vol. 168, pp. 698-707, 2018, http://dx.doi.org/10.1016/j.engstruct.2018.05.014.

[7] A. Yavas and C. O. Goker, "Impact of reinforcement ratio on shear behavior of I-shaped UHPC beams with and without fiber shear reinforcement," Materials, vol. 13, no. 7, pp. 1525, 2020, http://dx.doi.org/10.3390/ma13071525.

[8] T. L. Resende, D. C. T. Cardoso, and L. C. D. Shehata, "Influence of steel fibers on the dowel action of RC beams without stirrups," Eng. Struct., vol. 221, pp. 111044, 2020, http://dx.doi.org/10.1016/j.engstruct.2020.111044.

[9] International Federation for Structural Concrete, Model Code for Concrete Structures. Wilhelm Ernst \& Sohn, 2013.

[10] American Concrete Institute, Building Code Requirements for Structural Concrete, ACI 318, 2014, 524 p.

[11] American Concrete Institute, Design Considerations for Steel Fiber Reinforced Concrete, ACI 544.4R, 2018,44 p.

[12] Associação Brasileira de Normas Técnicas, Design of Fiber Reinforced Concrete Structures - Procedure, NBR 16935, 2021 (in Portuguese).

[13] Associação Brasileira de Normas Técnicas, Design of Concrete Structures - Procedure, NBR 6118, 2014 (in Portuguese).

[14] Japanese Society of Civil Engineers, Recommendations for Design and Construction of High-Performance Fiber Reinforced Cement Composites with Multiple Fine Cracks (HPFRCC). Concrete Committee, 2008.

[15] B. N. Moraes-Neto, J. A. O. Barros, and G. S. S. A. Melo, "A model for the prediction of the punching resistance of steel fibre reinforced concrete slabs centrically loaded," Constr. Build. Mater., vol. 46, pp. 211-223, 2013, http://dx.doi.org/10.1016/j.conbuildmat.2013.04.034.

[16] K.-K. Choi, M. M. Reda Taha, H.-G. Park, and A. K. Maji, "Punching shear strength of interior concrete slab-column connections reinforced with steel fibers," Cement Concr. Compos., vol. 29, no. 5, pp. 409-420, 2007, http://dx.doi.org/10.1016/j.cemconcomp.2006.12.003.

[17] P. P. F. Rodrigues, "Parâmetros de Dosagem do Concreto," 2. ed. São Paulo: ABCP, 1995.

[18] Associação Brasileira de Normas Técnicas, Concrete Steel Fibers - Specification, NBR 15530, 2007 (in Portuguese).

[19] Associação Brasileira de Normas Técnicas, Metallic Materials - Tensile Testing Part 1: Method of Test at Room Temperature, NBR 6892, 2013 (in Portuguese).

[20] L. D. S. Gomes, D. R. C. Oliveira, B. N. Moraes-Neto, A. B. Medeiros, A. N. Macedo, and F. A. C. Silva, "Experimental analysis of the efficiency of steel fibers on shear strength of beams," Lat. Am. J. Solids Struct., vol. 15, no. 7, Jul 2018, http://dx.doi.org/10.1590/1679-78254710.

Author contributions: DRC: conceptualization, funding acquisition, supervision, writing; AKLL: conceptualization, data curation, formal analysis, methodology, writing; AKLL, MVS and LFA: data curation, formal analysis.

Editors: Ricardo Carrazedo, Guilherme Aris Parsekian. 